\title{
Sustainable development of suppliers - a systematic review of the literature
}

Monika Jedynak

Jagiellonian University

Aneta Kuźniarska

Jagiellonian University

Karolina Mania

Jagiellonian University

\section{Introduction}

Today, sustainable development of suppliers is vital to increase the ability of suppliers to better meet the long-term needs of buyers. The article analyzes the occurrence of issues concerning sustainable development of suppliers in peer-reviewed scientific publications. The following research questions were asked:

- "Is there a gap in research in this thematic area?";

- "Is there a trend when it comes to publication time on a given topic?";

- "Which scientific journals publish articles on the sustainability of suppliers?";

- "From which countries do authors most often deal with the issues of sustainable development of suppliers?";

- "In what areas of research are the issues of sustainable development of suppliers addressed?".

The basic research method was a systematic literature review. The selected texts were selected based on the databases of EBSCO, ProQuest, JSTOR, Web of Science and Google Scholar. 


\section{Supplier development issues}

The term 'development of suppliers' was first introduced by Leeders in 1966 to emphasize the efforts undertaken by producers to increase the number and improve the efficiency of their suppliers ${ }^{1}$. Over time, in addition to supplier efficiency, other elements have appeared: improving supplier capacity ${ }^{2}$, knowledge transfer (including shared vision), as well as direct involvement and evaluation of suppliers ${ }^{3}$.

In the literature, development of suppliers occurs as an activity that takes place after the selection process ${ }^{4}$, because the evaluation and the subsequent selection of the supplier allow the buyer to effectively manage a sustainable portfolio of suppliers ${ }^{5}$. In specific sectors, such as the automotive sector, the development of suppliers may be preceded by the selection stage, among others, due to the earlier designing of delivered components in the just-in-time concept ${ }^{6}$.

The goal of development of suppliers is primarily to increase their ability to better meet the long-term needs of buyers ${ }^{7}$, and to monitor their behavior as well as their management - to reduce risk in mutual relations ${ }^{8}$. The implementation of these goals is supported by special supplier development programs that allow one the effective solving of problems of productivity and quality ${ }^{9}$, improve operational

1 M.R. Leenders, Suppliers development, "Journal of Purchasing” 1966, vol. 24, pp. 47-62.

2 D.R. Krause, R.B. Handfield, B.B. Tyler, The relationships between supplier development, commitment, social capital accumulation and performance improvement, "Journal of Operations Management" 2007, vol. 25, no. 2, pp. 528-545. Ibidem.

4 D.R. Krause, L.M. Ellram, Critical elements of supplier development: The buying-firm perspective, "European Journal of Purchasing and Supply Management" 1997, vol. 3, no. 1, pp. 21-31; S. Talluri, R. Narasimhan, A methodology for strategic sourcing, "European Journal of Operational Research" 2004, vol. 154, no. 1, pp. 236-250; C. Araz, I. Ozkarahan, Supplier evaluation and management system for strategic sourcing based on a new multicriteria sorting procedure, "International Journal of Production Economics" 2007, vol. 106, no. 2, pp. 585-606.

$5 \quad$ K. Foerstl et al., Managing supplier sustainability risks in a dynamically changing environment - Sustainable supplier management in the chemical industry, "Journal of Purchasing and Supply Management" 2010, vol. 16, no. 2, pp. 118-130.

6 D. Luzzini et al., The path of innovation: Purchasing and supplier involvement into new product development, "Industrial Marketing Management" 2015, vol. 47, pp. 109-120.

7 C.K. Hahn, C.A. Watts, K.Y. Kim, The Supplier Development Program: A Conceptual Model, "Journal of Purchasing and Materials Management" 1990, vol. 26, no. 2, pp. 2-7.

8 R. Cole, J. Aitken, Selecting suppliers for socially sustainable supply chain management: postexchange supplier development activities as pre-selection requirements, "Production Planning and Control" 2019, vol. 30, no. 14, pp. 1184-1202.

9 D.R. Krause, L.M. Ellram, Critical elements... 
efficiency ${ }^{10}$, build long-term competitive advantage and trust ${ }^{11}$. Supplier development programs may include, for example, education and training of the suppliers' staff, assessment of suppliers' performance, incentives for suppliers or direct financial investments ${ }^{12}$. Despite the fact that buyers are initiators of such activities, the benefits are mutual ${ }^{13}$. Among the benefits for suppliers from the existence of their development program is the increase in satisfaction and commitment ${ }^{14}$.

Traditionally, the focus of supplier development in producer - supplier relations has been on cost reduction, ongoing performance, quality management, implementation of new technologies and product design ${ }^{15}$, while, currently, the sustainable development of suppliers is being increasingly postulated ${ }^{16}$. Although ensuring compliance with CSR standards for the supplier may entail increased costs, expenditure of time and the need for specialized knowledge ${ }^{17}$, it is emphasized that the extension of supplier development programs by these standards is associated with assistance from the buyer, including the provision of support and necessary resources $^{18}$.

10 P.K. Humphreys, W.L. Li, L.Y. Chan, The impact of supplier development on buyer-supplier performance, "Omega” 2004, vol. 32, no. 2, pp. 131-143; D.R. Krause, T.V. Scannell, R.J. Calantone, A Structural Analysis of the Effectiveness of Buying Firms' Strategies to Improve Supplier Performance, "Decision Sciences" 2000, vol. 31, no. 1, pp. 33-55; S.B. Modi, V.A. Mabert, Supplier development: Improving supplier performance through knowledge transfer, "Journal of Operations Management" 2007, vol. 25, no. 1, pp. 42-64; S. Li, M. Kang, M.H. Haney, The effect of supplier development on outsourcing performance: the mediating roles of opportunism and flexibility, "Production Planning and Control" 2017, vol. 28, no. 6-8, pp. 599-609; M. Zhang, K.S. Pawar, S. Bhardwaj, Improving supply chain social responsibility through supplier development, "Production Planning and Control" 2017, vol. 28, no. 6-8, pp. 500-511.

11 H. Nagati, C. Rebolledo, Supplier development efforts: The suppliers' point of view, "Industrial Marketing Management” 2013, vol. 42, no. 2, pp. 180-188.

12 S. Li, M. Kang, M.H. Haney, The effect of supplier development...

13 C. Sancha et al., Does implementing social supplier development practices pay off?, "Supply Chain Management" 2015, vol. 20, no. 4, pp. 389-403.

14 P.W.T. Ghijsen, J. Semeijn, S. Ernstson, Supplier satisfaction and commitment: The role of influence strategies and supplier development, "Journal of Purchasing and Supply Management" 2010, vol. 16, no. 1, pp. 17-26.

15 S. Talluri, R. Narasimhan, W. Chung, Manufacturer cooperation in supplier development under risk, "European Journal of Operational Research" 2010, vol. 207, no. 1, pp. 165-173.

16 C. Sancha, A. Longoni, C. Giménez, Sustainable supplier development practices: Drivers and enablers in a global context, "Journal of Purchasing and Supply Management" 2015, vol. 21, no. 2, pp. 95-102; S. Li, M. Kang, M.H. Haney, The effect of supplier development...; M. Zhang, K.S. Pawar, S. Bhardwaj, Improving supply chain social responsibility...

17 S. Ayuso, M. Roca, R. Colomé, SMEs as "transmitters" of CSR requirements in the supply chain, "Supply Chain Management" 2013, vol. 18, no. 5, pp. 497-508.

18 C. Giménez, E.M. Tachizawa, Extending sustainability to suppliers: A systematic literature review, "Supply Chain Management" 2012, vol. 17, no. 5, pp. 531-543. 


\section{Research methodology}

A systematic review of the literature allows the identification of the current state of knowledge in a given area, understand a given issue, diagnose gaps, and, as a consequence, leads to further research aimed at bridging them ${ }^{19}$. It provides the basis for the development of new knowledge and fosters the development of theory in areas that have not yet been explored ${ }^{20}$. This method facilitates the identification, assessment, and interpretation of existing research in a given field while introduction of the possibility of multiple repetition of tests ${ }^{21}$.

The systematic review of articles related to the topic of sustainable development of suppliers carried out in the article was to answer the following research questions:

- "Is there a research gap in the thematic area?";

- "Is there a trend when it comes to publication time on a given topic?";

- "Which scientific journals publish articles on the sustainable development of suppliers?";

- "From which countries do authors most often deal with the issues of sustainable development of suppliers?".

Within the research, an approach has been adopted based on the review of scientific databases, which, as indicated by Czakon, are electronic, scientific databases containing scientific publications on a global scale ${ }^{22}$. As part of the study, the following electronic databases were selected for review: EBSCO, ProQuest, JSTOR, Web of Science and Google Scholar.

The search strategy started by defining the criteria for the automated search of publications in electronic databases, due to the fact that the systematic approach requires that process-related elements should be selected for inclusion on the basis of their usefulness and rigor for the research conducted ${ }^{23}$. As part of it, a decision

19 A. Orłowska, Z. Mazur, M. Łaguna, Systematyczny przeglqad literatury: Na czym polega i czym różni się od innych przeglądów, "Ogrody Nauk i Sztuk” 2017, no. 7, pp. 350-363.

20 J. Webster, R.T. Watson, Analyzing the past to prepare for the future: Writing a literature review, "MIS Quarterly" 2002, vol. 26, no. 2, pp. 13-23.

21 S. Seuring, M. Müller, From a literature review to a conceptual framework for sustainable supply chain management, "Journal of Cleaner Production” 2008, no. 16, pp. 1699-1710.

22 W. Czakon, Metodyka systematycznego przeglądu literatury, "Przegląd Organizacji" 2011, no. 3, pp. 57-61.

23 A. Booth, A. Sutton, D. Papaioannou, Systematic approaches to a successful literature review, Sage Publications, London 2012, p. 19, https://www.researchgate.net/publication /235930866_Systematic_Approaches_to_a_Successful_Literature_Review (accessed: 19.10.2019). 
was made to apply the following inclusion criteria, i.e. including publications in the database 24 :

- the search criteria will only cover articles published in English without the specification of the time period of their publication;

- all publications will be qualified within the fields of economics, economy, management;

- search criteria (keywords) will be included only in the title, which reflects the essential, rather than the accessory research category for the searched keywords;

- to ensure an appropriate level of publication quality, the search will be based only on peer-reviewed articles;

- the search rigor will only cover works available in full version ( full text).

The next step in the research process was to select keywords based on which the electronic databases were searched. As a result of the discussion of the research team, a combination of the following words was selected: sustainable, development and supplier, which were combined by one of Boole's logical operators in the process of searching databases, i.e. the phrase 'and'.

Using the classification scheme presented above, a literature database was initially created consisting of 29 publications, which, after removing duplicate papers, allowed the creation of a reference repository which covered a total of 23 articles (see Table 1).

Table 1. The process of creating the literature database in quantitative terms

\begin{tabular}{|l|r|r|r|r|r|}
\hline \multicolumn{1}{|c|}{ Search criteria } & \multicolumn{1}{c|}{$\begin{array}{c}\text { EBSCO } \\
(26.09 .19)\end{array}$} & $\begin{array}{c}\text { ProQuest } \\
(27.09 .19)\end{array}$ & $\begin{array}{c}\text { JSTOR } \\
(27.09 .19)\end{array}$ & $\begin{array}{c}\text { Web of Science } \\
(30.09 .2019)\end{array}$ & $\begin{array}{c}\text { Google Scholar } \\
(30.09 .2019)\end{array}$ \\
\hline "sustainable" in title & 1689141 & 188970 & 2685 & 6906 & 391000 \\
\hline "development" in title & 514261 & 38626 & 1178 & 3355 & 127000 \\
\hline "supplier" in title & 278 & 26 & 0 & 1 & 44 \\
\hline Full text & 163 & 19 & & 1 & 19 \\
\hline Peer reviewed & 75 & 3 & & 1 & 6 \\
\hline After verification the titles & 19 & 3 & & 1 & 6 \\
\hline Total without duplicates & 23 & \multicolumn{5}{|c|}{} \\
\hline
\end{tabular}

Source: own study.

The articles selected during the database search became the subject for further analysis. Their small number indicates the existence of a research gap in the area of sustainable development of suppliers.

24 R.E. Slavin, Best evidence synthesis: an intelligent alternative to meta-analysis, "Journal of Clinical Epidemiology" 1995, vol. 48(1), pp. 9-18. 


\section{Bibliometric analysis of articles by journals, year of publication and affiliation of the authors}

The next stage of the research was to identify the titles of magazines in which the topic of sustainable development of suppliers was taken up (see Figure 1).

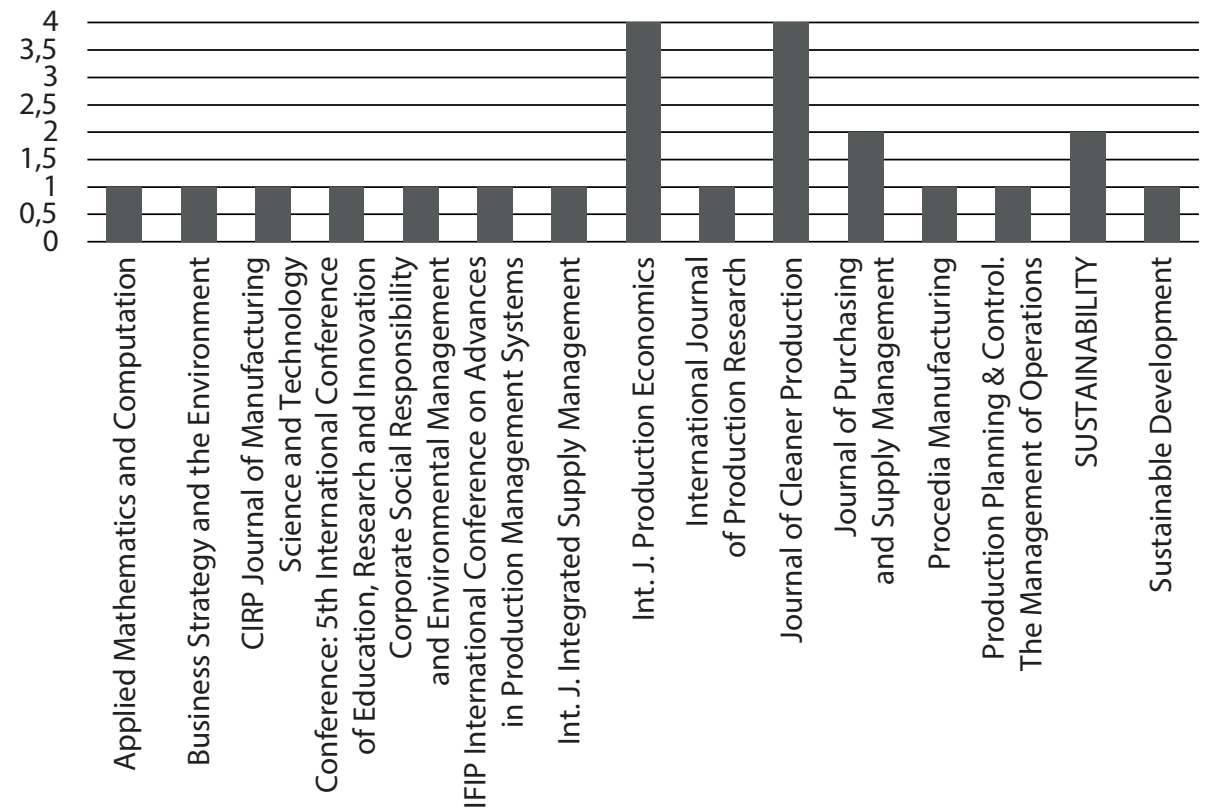

Figure 1. Issues of sustainable development of suppliers in scientific publications

Source: own study.

The largest number of articles was published in the "International Journal of Production Economics" and the "Journal of Cleaner Production", which is not surprising due to the connection with materials flow cycle and finished products in production processes. As can be seen, the topic is also discussed in the context of supply management ("Journal of Purchasing and Supply Management") or the currently widely discussed topic of sustainable development ("SUSTAINABILITY", "Sustainable Development”, 'Corporate Social Responsibility”, and “Environmental Management", "Business Strategy and the Environment").

A systematic review of the literature on the sustainable development of suppliers enabled the selection of 23 articles that were published in the years 2010-2019. The next stage of the research was, therefore, the analysis of the number of publications in individual years (see Figure 2). 
Due to the limited time range of publication found when searching for the terms - the first publication is from 2010 - it can be concluded that this topic has been undertaken relatively recently. It should be pointed out that since 2013 there has been a gradual upward trend in the number of articles on the sustainable development of suppliers.

Next, the authors of the publications' country of origin were subjected to bibliometric analysis according to their declared affiliation. In total, 70 affiliations were obtained (see Figure 3).

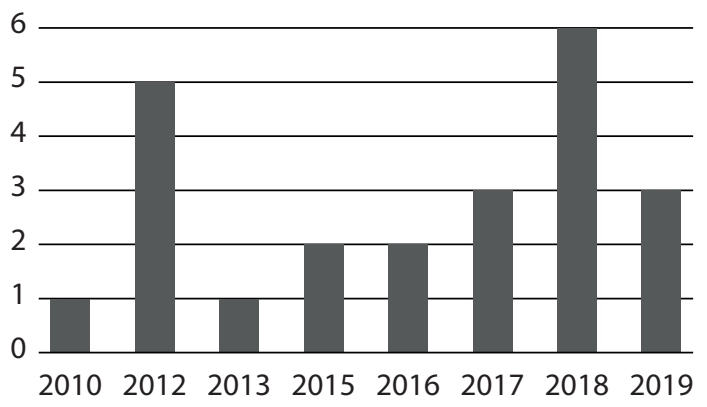

Figure 2. Issues of sustainable development of suppliers in individual years Source: own study.

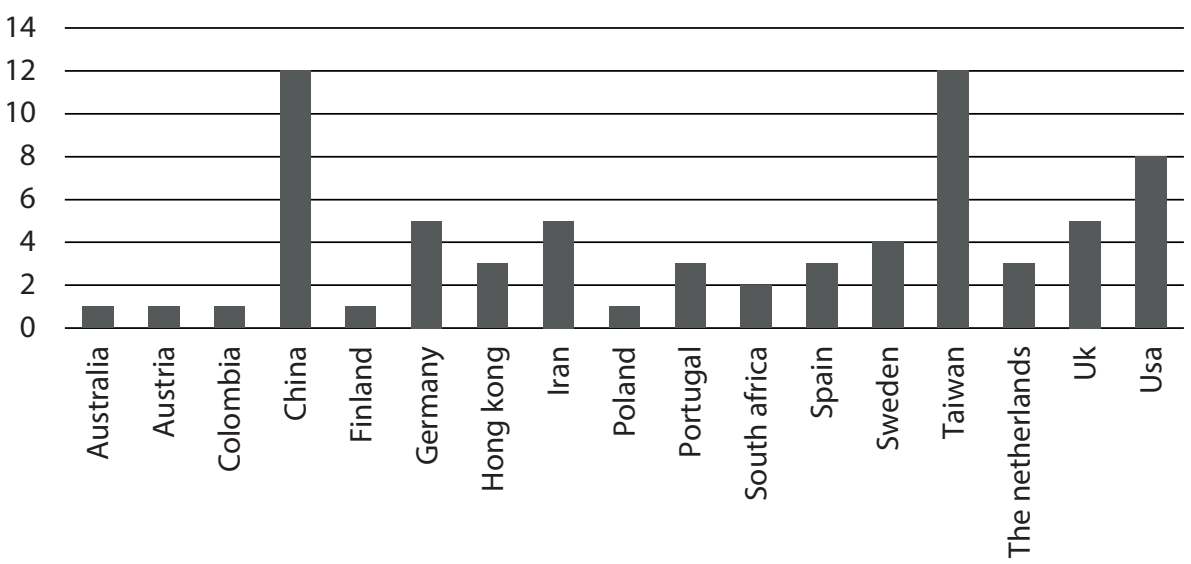

Figure 3. Issues of sustainable development of suppliers according to authors' affiliations

Source: own study.

As indicated in the chart, the largest declared number of authors' affiliations (12 each) comes from China and Taiwan, 8 from the USA, 5 from each Great Britain, Germany and Iran, 4 from Sweden. 


\section{Keyword Analysis}

Although bibliometric studies are auxiliary to content analysis, they allow the assessment of individual features of the set, providing important information about the importance of the studied topics for science in general ${ }^{25}$. The methodology of a systematic literature review based on content analysis techniques is based on a quantitative assessment, allowing verification of frequency, i.e. an indication of the frequency of occurrence of the studied features ${ }^{26}$. The overriding goal of this exploratory stage of research is to highlight common areas and streams of research ${ }^{27}$.

One aspect that may be the subject of research in terms of frequency of occurrence is keywords ${ }^{28}$. The analysis of their occurrence enables the determination of the research field as well as to indicate connections with other fields of science ${ }^{29}$.

The authors analyzed all keywords from 23 scientific articles selected at the stage of a systematic review of the literature (see Table 1). Among the 23 texts mentioned, two had no information on the allocation of keywords by the authors (items [01] and [17] in Table 2).

Table 2. List of analyzed scientific publications

\begin{tabular}{|c|l|l|c|}
\hline $\begin{array}{c}\text { Reference } \\
\text { number }\end{array}$ & \multicolumn{1}{|c|}{ Author(s) } & \multicolumn{1}{|c|}{ Titles } & Year \\
\hline$[01]$ & $\begin{array}{l}\text { Usama Awan, } \\
\text { Robert Sroufe, } \\
\text { Andrzej Kraslawski }\end{array}$ & $\begin{array}{l}\text { Creativity enables sustainable development: Supplier } \\
\text { engagement as a boundary condition for the positive } \\
\text { effect on green innovation }\end{array}$ & 2019 \\
\hline$[02]$ & $\begin{array}{l}\text { Rosanna Cole, } \\
\text { James Aitken }\end{array}$ & $\begin{array}{l}\text { Selecting suppliers for socially sustainable supply chain } \\
\text { management: post-exchange supplier development } \\
\text { activities as pre-selection requirements }\end{array}$ & 2019 \\
\hline$[03]$ & $\begin{array}{l}\text { Marise Vermeulen, } \\
\text { Gerd Adriaan } \\
\text { Oosthuizen }\end{array}$ & $\begin{array}{l}\text { Strategic Local Manufacturing Supplier Development } \\
\text { Roadmap as a Decision Support Tool }\end{array}$ & 2019 \\
\hline$[04]$ & $\begin{array}{l}\text { Zachary S. Rogers, } \\
\text { Craig R. Carter, } \\
\text { Virginia Kwan }\end{array}$ & $\begin{array}{l}\text { Making tough choices: A policy capturing approach } \\
\text { to evaluating the tradeoffs in sustainable supplier } \\
\text { development initiatives }\end{array}$ & 2019 \\
\hline
\end{tabular}

25 M.O. Columb, A.G. Lalkhen, Systematic reviews and meta-analysis, "Current Anaesthesia and Critical Care" 2005, vol. 16(6), pp. 391-393.

26 W. Czakon, Metodyka...

27 C. Giménez, E. Tachizawa, Extending sustainability to suppliers...

28 H.N.Su, P.C. Lee, Mapping knowledge structure by keyword co-occurrence: A first look at journal papers in technology foresight, "Scientometrics" 2010, no. 85(1), pp. 65-79.

29 W. Czakon, P. Klimas, Sieci oraz firmy kotwice - ich znaczenie w gospodarce opartej na wiedzy, Management and IT - dilemmas and directions of development, 4th Science Forum University of Economics, Katowice 2010. 


\begin{tabular}{|c|c|c|c|}
\hline $\begin{array}{c}\text { Reference } \\
\text { number }\end{array}$ & Author(s) & Titles & Year \\
\hline [05] & $\begin{array}{l}\text { Yuangao Chen, } \\
\text { Shuo Wang, } \\
\text { Jianrong Yao, } \\
\text { Yixiao Li, Shuiqing } \\
\text { Yang }\end{array}$ & $\begin{array}{l}\text { Socially responsible supplier selection and sustainable } \\
\text { supply chain development: A combined approach } \\
\text { of total interpretive structural modeling and fuzzy } \\
\text { analytic network process }\end{array}$ & 2018 \\
\hline [06] & $\begin{array}{l}\text { Fu Jia, Laura } \\
\text { Zuluaga-Cardona, } \\
\text { Adrian Bailey, } \\
\text { Ximena Rueda }\end{array}$ & $\begin{array}{l}\text { Sustainable supply chain management in developing } \\
\text { countries: An analysis of the literature }\end{array}$ & 2018 \\
\hline [07] & $\begin{array}{l}\text { Kamran Rashidi, } \\
\text { Reza Farzipoor } \\
\text { Sean }\end{array}$ & $\begin{array}{l}\text { Incorporating dynamic concept into gradual } \\
\text { efficiency: Improving suppliers in sustainable supplier } \\
\text { development }\end{array}$ & 2018 \\
\hline [08] & $\begin{array}{l}\text { Peng Jiang, } \\
\text { Yi-Chung Hu, Ghi- } \\
\text { Feng-Yen, } \\
\text { Shu-Ju Tsao }\end{array}$ & $\begin{array}{l}\text { Green supplier selection for sustainable development } \\
\text { of the automotive industry using grey decision-making }\end{array}$ & 2018 \\
\hline [09] & $\begin{array}{l}\text { Chin-Tsai Lin, } \\
\text { Kuang-Peng Hung, } \\
\text { Shu-Hsien Hu }\end{array}$ & $\begin{array}{l}\text { A Decision-Making Model for Evaluating and } \\
\text { Selecting Suppliers for the Sustainable Operation and } \\
\text { Development of Enterprises in the Aerospace Industry }\end{array}$ & 2018 \\
\hline [10] & $\begin{array}{l}\text { Hadi Shabanpour, } \\
\text { Reza Farzipoor } \\
\text { Sean, Saeed } \\
\text { Yousefi }\end{array}$ & $\begin{array}{l}\text { Forecasting efficiency of green suppliers by dynamic } \\
\text { data envelopment analysis and artificial neural } \\
\text { networks }\end{array}$ & 2017 \\
\hline [11] & Guo-Ciang Wu & $\begin{array}{l}\text { Effects of Socially Responsible Supplier Development } \\
\text { and Sustainability-Oriented Innovation on Sustainable } \\
\text { Development: Empirical Evidence from SMEs }\end{array}$ & 2017 \\
\hline [12] & $\begin{array}{l}\text { Ashkan } \\
\text { Hafezalkotob }\end{array}$ & $\begin{array}{l}\text { Competition of domestic manufacturer and foreign } \\
\text { supplier under sustainable development objectives } \\
\text { of government }\end{array}$ & 2017 \\
\hline [13] & $\begin{array}{l}\text { Chia-Nan Wang, } \\
\text { Ying-Fang Huang, } \\
\text { Thi-Nham Le, } \\
\text { Thanh-Tuan Ta }\end{array}$ & $\begin{array}{l}\text { An Innovative Approach to Enhancing the Sustainable } \\
\text { Development of Japanese Automobile Suppliers }\end{array}$ & 2016 \\
\hline [14] & $\begin{array}{l}\text { Konrad Zimmer, } \\
\text { Magnus Fröhlig, } \\
\text { Frank Schultmann } \\
\end{array}$ & $\begin{array}{c}\text { Sustainable supplier management - a review of models } \\
\text { supporting sustainable supplier selection, monitoring } \\
\text { and development }\end{array}$ & 2016 \\
\hline [15] & $\begin{array}{l}\text { Cristina Sancha, } \\
\text { Annachiara } \\
\text { Longoni, Cristina } \\
\text { Giménez }\end{array}$ & $\begin{array}{l}\text { Sustainable supplier development practices: Drivers } \\
\text { and enablers in a global context }\end{array}$ & 2015 \\
\hline [16] & $\begin{array}{l}\text { Muratcan Erkul, } \\
\text { Hale Kaynak, Ivan } \\
\text { Montiel }\end{array}$ & $\begin{array}{l}\text { Supplier relations and sustainable operations: the roles } \\
\text { of codes of conduct and human resource development }\end{array}$ & 2015 \\
\hline$[17]$ & $\begin{array}{l}\text { Alex A. Alblas, } \\
\text { Kristin Peters, } \\
\text { Hans Wortmann }\end{array}$ & $\begin{array}{l}\text { Process Alignment for Sustainable Product } \\
\text { Development: The Essential Role of Supplier and } \\
\text { Customer Involvement Processes }\end{array}$ & 2013 \\
\hline
\end{tabular}


Table 2 (continued)

\begin{tabular}{|c|c|c|c|}
\hline $\begin{array}{l}\text { Reference } \\
\text { number }\end{array}$ & Author(s) & Titles & Year \\
\hline [18] & $\begin{array}{l}\text { Xiaoyong Fu, } \\
\text { Qinghua Zhu, } \\
\text { Joseph Sarkis }\end{array}$ & $\begin{array}{l}\text { Evaluating green supplier development programs } \\
\text { at a telecommunications systems provider }\end{array}$ & 2012 \\
\hline [19] & $\begin{array}{l}\text { Christina } \\
\text { W.Y. Wong, Kee- } \\
\text { hung Lai, Kuo- } \\
\text { Chung Shang, } \\
\text { Chin-Shan Lu, } \\
\text { T.K.P. Leung }\end{array}$ & $\begin{array}{l}\text { Green operations and the moderating role } \\
\text { of environmental management capability of suppliers } \\
\text { on manufacturing firm performance }\end{array}$ & 2012 \\
\hline [20] & $\begin{array}{l}\text { Rainy X.A. Lu, } \\
\text { Peter K.C. Lee, } \\
\text { T. C.E. Cheng }\end{array}$ & $\begin{array}{l}\text { Socially responsible supplier development: Construct } \\
\text { development and measurement validation }\end{array}$ & 2011 \\
\hline [21] & $\begin{array}{l}\text { Philipp Goebel, } \\
\text { Carsten Reuter, } \\
\text { Richard Pibernik, } \\
\text { Christina } \\
\text { Sichtmann } \\
\end{array}$ & $\begin{array}{l}\text { The influence of ethical culture on supplier selection } \\
\text { in the context of sustainable sourcing }\end{array}$ & 2012 \\
\hline [22] & $\begin{array}{l}\text { Teresa Dieguez, } \\
\text { Filomena Amador, } \\
\text { Jose Porfirio }\end{array}$ & $\begin{array}{l}\text { The Balance between the supply of Portuguese higher } \\
\text { education institutions and the emerging challenges } \\
\text { of sustainable development: the case of automotive } \\
\text { suppliers industry }\end{array}$ & 2012 \\
\hline [23] & $\begin{array}{l}\text { Erik Sundin, } \\
\text { Anna Ohrwall } \\
\text { Ronnback, } \\
\text { Tomohiko Sakao }\end{array}$ & $\begin{array}{l}\text { From component to system solution supplier: Strategic } \\
\text { warranty management as a key to efficient integrated } \\
\text { product/service engineering }\end{array}$ & 2010 \\
\hline
\end{tabular}

Source: own study.

The final analysis included 106 keywords, out of which 85 were selected (within 23 scientific articles). These were then grouped into 9 thematic (research) areas:

- Sustainable development;

- Methodology;

- Supplier management;

- Tools;

- Value chain;

- Markets;

- Concept;

- Sector and

- Strategy.

The conducted keyword analysis allowed the identification of research areas in connection with the keywords used to identify them and reference numbers assigned to individual texts, as shown in Table 3. 
Table 3. Key research areas

\begin{tabular}{|c|c|c|}
\hline $\begin{array}{c}\text { Key research } \\
\text { areas }\end{array}$ & Keywords & $\begin{array}{c}\text { Number } \\
\text { of Publications }\end{array}$ \\
\hline $\begin{array}{l}\text { Sustainable } \\
\text { development }\end{array}$ & $\begin{array}{l}\text { - sustainable supply chain management } \\
\text { - socially responsible purchasing } \\
\text { - sustainable supplier development } \\
\text { - socially responsible supplier } \\
\text { - sustainable supply chain } \\
\text { - sustainability } \\
\text { - green supplier } \\
\text { - sustainable development } \\
\text { - sustainable enterprise operation } \\
\text { - cSR } \\
\text { - socially responsible supplier development } \\
\text { - sustainability-oriented innovation } \\
\text { - sustainable development objectives } \\
\text { - sustainable human resource development } \\
\text { - sustainability performance } \\
\text { - environmental supply chain management } \\
\text { - green operations } \\
\text { - ethical behavior } \\
\text { - ethical culture } \\
\text { - education for sustainable development }\end{array}$ & $\begin{array}{l}02] \\
{[02]} \\
{[04],[15]} \\
{[05],[11]} \\
{[05]} \\
{[06],[07],[14],[21]} \\
{[08]} \\
{[08]} \\
{[09]} \\
{[06]} \\
{[11]} \\
{[11]} \\
{[12]} \\
{[16]} \\
{[16]} \\
{[18]} \\
{[19]} \\
{[21]} \\
{[21]} \\
{[22]}\end{array}$ \\
\hline Methodology & $\begin{array}{l}\text { - behavioral agency theory } \\
\text { - } \text { - funP } \\
\text { - TISM decision } \\
\text { - systematic literature review } \\
\text { - content analysis } \\
\text { - most productive scale size } \\
\text { - data envelopment analysis (DEA) } \\
\text { - } \text { analytical network process } \\
\text { - grey relational analysis } \\
\text { - modified Delphi method } \\
\text { - analytic network process } \\
\text { - dynamic data envelopment analysis } \\
\text { - game theory } \\
\text { - TRIZ } \\
\text { - function and attribute analysis model } \\
\text { - contradiction matrix } \\
\text { - literature review } \\
\text { - hierarchical linear modelling } \\
\text { - resource-based view } \\
\text { - relational view } \\
\text { - institutional theory } \\
\text { - grey numbers }\end{array}$ & $\begin{array}{l}02] \\
{[05]} \\
{[05]} \\
{[05]} \\
{[06]} \\
{[06]} \\
{[07]} \\
{[07]} \\
{[08]} \\
{[08]} \\
{[09]} \\
{[09]} \\
{[10]} \\
{[12]} \\
{[13]} \\
{[13]} \\
{[13]} \\
{[14]} \\
{[15]} \\
{[16]} \\
{[16]} \\
{[16]} \\
{[18]}\end{array}$ \\
\hline
\end{tabular}


Table 3 (continued)

\begin{tabular}{|c|c|c|}
\hline $\begin{array}{l}\text { Key research } \\
\text { areas }\end{array}$ & Keywords & $\begin{array}{c}\text { Number } \\
\text { of Publications }\end{array}$ \\
\hline & $\begin{array}{l}\text { - } \text { DEMATEL } \\
\text { - } \text { PSS } \\
\text { - IPSE } \\
\text { - IPS2 }\end{array}$ & \begin{tabular}{|l}
{$[08],[18]$} \\
{$[23]$} \\
{$[23]$} \\
{$[23]$}
\end{tabular} \\
\hline $\begin{array}{l}\text { Supplier } \\
\text { management }\end{array}$ & $\begin{array}{l}\text { - supplier selection } \\
\text { - supplier development } \\
\text { - supplier improvement } \\
\text { - green supplier selection } \\
\text { - supplier evaluation } \\
\text { - purchasing } \\
\text { - sustainable operations } \\
\text { - } \text { evaluation criteria } \\
\text { - supplier integration } \\
\text { - codes of conduct } \\
\text { - knowledge transfer } \\
\text { - environmental management } \\
\text { - scale development and validation } \\
\text { - product/service system }\end{array}$ & $\begin{array}{l}{[02],[09],[14],[21]} \\
{[03],[18],[20]} \\
{[07]} \\
{[10]} \\
{[09]} \\
{[14]} \\
{[16]} \\
{[14]} \\
{[15]} \\
{[16]} \\
{[16]} \\
{[16]} \\
{[19]} \\
{[20]} \\
{[23]}\end{array}$ \\
\hline Tool & $\begin{array}{l}\text { - decision support systems } \\
\text { - survey } \\
\text { - forecasting of future efficiency }\end{array}$ & \begin{tabular}{|l|}
{$[14]$} \\
{$[20]$} \\
{$[10]$}
\end{tabular} \\
\hline Value chain & $\begin{array}{l}\text { - value creation } \\
\text { - } \text { cooperation and competition } \\
\text { - } \text { scale efficient } \\
\text { - policy capturing }\end{array}$ & $\begin{array}{l}03] \\
{[12]} \\
{[16]} \\
{[07]} \\
{[04]}\end{array}$ \\
\hline Markets & $\begin{array}{l}\text { - developing countries } \\
\text { - Taiwan } \\
\end{array}$ & \begin{tabular}{|l|}
{$[06]$} \\
{$[11]$} \\
\end{tabular} \\
\hline Concept & $\begin{array}{ll}\text { - } & \text { outsourcing } \\
\text { - lean manufacturing } \\
\text { - } & \text { strategic warranty management }\end{array}$ & $\begin{array}{l}12] \\
{[13]} \\
{[23]}\end{array}$ \\
\hline Sector & $\begin{array}{l}\text { - } \text { government financial intervention } \\
\text { - local manufacturing } \\
\text { - } \text { institutional pressures } \\
\text { - education } \\
\text { - manufacturing } \\
\text { - SMEs } \\
\text { - aerospace industry }\end{array}$ & $\begin{array}{l}12] \\
{[03]} \\
{[13]} \\
{[15]} \\
{[22]} \\
{[23]} \\
{[11]} \\
{[09]} \\
\end{array}$ \\
\hline Strategy & $\begin{array}{l}\text { - } \text { product stewardship } \\
\text { - } \text { process stewardship }\end{array}$ & \begin{tabular}{|l|}
{$[19]$} \\
{$[19]$}
\end{tabular} \\
\hline
\end{tabular}

Source: own study. 
The results of the keyword review showed that the studied subject is most often associated with the following areas: Sustainable development (16 publications), Methodology (14 publications), Supply management (13 publications), Sector (8 publications), Value chain (5 publications), Tools and Concept (3 publications each), Markets (2 publications) and Strategy (1 publication).

The analysis of the relationships between the fields selected above allows one to conclude that the studied topic of sustainable development of suppliers clearly falls under the category of sustainable development. Being the most numerous in the collection discussed (16 publications out of 21 items), it sets the framework for trends of research correlated with other selected fields ${ }^{30}$. The concept of sustainable development understood as a socio-economic concept based on respect for the laws of nature and the human environment assumes new ways of organizing and managing the economy ${ }^{31}$. This, in turn, directs one to the category of supply management (13 publications out of 21 items), defined within the framework of the scope of research on suppliers, described in point 2 of this publication ${ }^{32}$. The most common keywords, i.e. supplier selection and supplier development, are part of the important currents of research in the selected category ${ }^{33}$.

Other concepts: Sector, Value chain, Tools, Concept, Markets, and Strategy oscillate around the category of strategic management, referring to strategic tools for analyzing individual entities (in relation to their markets), in recognizing their strengths and weaknesses affecting the competitive advantage (or lack thereof) ${ }^{34}$.

30 T. Waas, A. Verbruggen, T. Wright, University research for sustainable development: definition and characteristics explored, "Journal of Cleaner Production", May 2010, vol. 18, issue 7, pp. 629-636.

31 Attempts to normatively define the concept of "sustainable development" were initiated by the United Nations, from the Stockholm conference on "The human environment" organized in 1972 to the second "Earth Summit" held in 1992 in Rio de Janeiro. The result of these debates was the development of two documents presenting the philosophy of sustainable development and basic principles: the Rio Declaration and Agenda 21 - United Nations Conference on Environment \& Development Rio de Janerio, Brazil, 3 to 14 June 1992 AGENDA 21, https://sustainabledevelopment.un.org/content/documents/Agenda21.pdf (accessed: 21.10.2019). A. Fearne, M. Garcia, B. Dent, Dimensions of sustainable value chains: Implications for value chain analysis, "Supply Chain Management” 2012, vol. 17(6), pp. 575-581.

32 K. Choon Tan, A framework of supply chain management literature, "European Journal of Purchasing and Supply Management”, March 2001, vol. 7, issue 1, pp. 39-48.

33 L. de Boer, E. Labro, P. Morlacchi, A review of methods supporting supplier selection, "European Journal of Purchasing and Supply Management", June 2001, vol. 7, issue 2, pp. 75-89.

34 J. Tan, S. Zailani, Green Value Chain in the Context of Sustainability Development and Sustainable Competitive Advantage, "Global Journal of Environmental Research" 2009, vol. 3(3), pp. 234-245. 
Being uniquely correlated with the value chain concept developed by Michael E. Porter, they close the whole keyword categorization analysis and demonstrate its consistency 35 .

The second of the most frequently occurring categories - Methodology (14 publications out of 21 items) allows one to assess which research tools were used by the authors within the topics discussed ${ }^{36}$. A uniform quantitative distribution of each keyword indicates that researchers followed a variety of research methodologies, from a literature review to game theory.

\section{Conclusions}

The analysis of publications indicates that the topic of sustainable development of suppliers refers to diverse research areas and is the subject of multi-faceted analysis. Bibliometric and contextual analyses allowed the formulation of answers to the research questions.

The relatively small number of peer-reviewed scientific publications on the sustainable development of suppliers present in the selected databases (23) and the time of their publication (2010-219) indicates that it is of moderate and relatively recent interest to researchers. In order to determine whether there is a research gap, one should examine the occurrence of the subject in the so-called "gray literature", which shows a much greater relevance of the discussed subjects compared to scientific sources ${ }^{37}$. The small number of publications also negates the determination of whether there is a trend in terms of publication time.

Scientific journals in which articles on sustainable development of suppliers are published have a diverse profile, which proves that the issue of sustainable development of suppliers is embedded in various and diverse research areas. This implicitly confirms its high research potential. The authors who undertook the analyzed issues come from different countries, which means that the scientific discussion is conducted internationally.

Sustainable development of suppliers is the subject of study in numerous research areas. This issue is most closely in relation to the issue of sustainable development,

35 M.E. Porter, Competitive Advantage: Creating and Sustaining Superior Performance, The Free Press, New York 1985.

36 W. Czakon (red.), Podstawy metodologii badań w naukach o zarzq̨dzaniu, Wolters Kluwer Polska, Warszawa 2015; K. Choon Tan, A framework...

37 R.J. Adams, P. Smart, A.S. Huff, Shades of Grey: Guidelines for Working with the Grey Literature in Systematic Reviews for Management and Organizational Studies, "International Journal of Management Reviews" 2017, vol. 19, no. 4, pp. 432-454; L. McAuley et al., Does the inclusion of grey literature influence estimates of intervention effectiveness reported in metaanalyses?, "The Lancet" 2000, vol. 356, no. 9237, pp. 1228-1231. 
which allows us to conclude that the role of suppliers in the sustainable development of enterprises is significant. Due to the fact that the subject of the analysis is suppliers, a reference to the concept of supply management and value chain has also been identified.

The analyzed issues are discussed in the context of diverse sectors, mainly related to physical flows (manufacturing, automobile industry, aerospace industry), but also appear in relation to sectors related to services (financial or educational), which may indicate the important role of suppliers in shaping the sustainable development of organizations belonging to various sectors.

The research conducted shows that it seems sensible to undertake further research aimed at identifying any potential research gaps. The belief in its existence is based on the small number of peer-reviewed publications that were identified in relation to the studied topic. The postulate for further research also includes an indication of the promising directions for future research.

Among the interesting directions of this research on the issue of sustainable development of suppliers, these are, among others:

- examination of the role played by suppliers in the sustainable development of the organization;

- analysis of the inclusion of the issues in other management concepts, such as CSR or supply chain management;

- analysis of the need to provide guidelines concerning to what extent organizations should include suppliers in sustainable development.

References

Adams R.J., Smart P., Huff A.S., Shades of Grey: Guidelines for Working with the Grey Literature in Systematic Reviews for Management and Organizational Studies, "International Journal of Management Reviews" 2017, vol. 19, no. 4, pp. 432-454.

Alblas A.A., Peters K., Wortmann H., Process Alignment for Sustainable Product Development: The Essential Role of Supplier and Customer Involvement Processes, 20th Advances in Production Management Systems (APMS), State College 2013, pp. 556-556.

Araz C., Ozkarahan I., Supplier evaluation and management system for strategic sourcing based on a new multicriteria sorting procedure, "International Journal of Production Economics" 2007, vol. 106, no. 2, pp. 585-606.

Awan U., Sroufe R., Kraslawski A., Creativity enables sustainable development: Supplier engagement as a boundary condition for the positive effect on green innovation, "Journal of Cleaner Production" 2019, no. 116, pp. 172-185.

Ayuso S., Roca M., Colomé R., SMEs as "transmitters" of CSR requirements in the supply chain, "Supply Chain Management" 2013, vol. 18, no. 5, pp. 497-508.

Boer L. de, Labro E., Morlacchi P., A review of methods supporting supplier selection, "European Journal of Purchasing and Supply Management", June 2001, vol. 7, issue 2, pp. 75-89. 
Booth A., Sutton A., Papaioannou D., Systematic approaches to a successful literature review, Sage Publications, London 2012, https://www.researchgate.net/publication/235930866_Syst ematic_Approaches_to_a_Successful_Literature_Review (accessed: 19.10.2019).

Chen Y., Wang S., Yao J., Li Y., Yang S., Socially responsible supplier selection and sustainable supply chain development: A combined approach of total interpretive structural modeling and fuzzy analytic network process, "Business Strategy and the Environment" 2018, no. 27, pp. 1708-1719.

Choon Tan K., A framework of supply chain management literature, "European Journal of Purchasing and Supply Management”, March 2001, vol. 7, issue 1, pp. 39-48.

Cole R., Aitken J., Selecting suppliers for socially sustainable supply chain management: post-exchange supplier development activities as pre-selection requirements, "Production Planning and Control" 2019, vol. 30, no. 14, pp. 1184-1202.

Columb M.O., Lalkhen A.G., Systematic reviews and meta-analysis, "Current Anaesthesia and Critical Care" 2005, vol. 16(6), pp. 391-393.

Czakon W., Metodyka systematycznego przeglqdu literatury, "Przegląd Organizacji" 2011, no. 3, pp. 57-61.

Czakon W., Klimas P., Sieci oraz firmy kotwice - ich znaczenie w gospodarce opartej na wiedzy, Management and IT - dilemmas and directions of development, 4th Science Forum University of Economics, Katowice 2010.

Czakon W. (red.), Podstawy metodologii badań w naukach o zarzq̨dzaniu, Wolters Kluwer Polska, Warszawa 2015.

Dieguez T., Amador F., Porfirio J., The Balance between the supply of Portuguese higher education institutions and the emerging challenges of sustainable development: the case of automotive suppliers industry, [in:] Proceedings of ICERI2012 (Fifth International Conference of Education, Research and Innovation), Madrid 2012, pp. 3485-3496.

Erkul M., Kaynak H., Montiel I., Supplier relations and sustainable operations: the roles of codes of conduct and human resource development, "International Journal of Integrated Supply Management" 2015, vol. 9, no. 3, pp. 225-249.

Fearne A., Garcia M., Dent B., Dimensions of sustainable value chains: Implications for value chain analysis, "Supply Chain Management" 2012, vol. 17(6), pp. 575-581.

Foerstl K., Reuter C., Hartmann E., Blome C., Managing supplier sustainability risks in a dynamically changing environment - Sustainable supplier management in the chemical industry, "Journal of Purchasing and Supply Management" 2010, vol. 16, no. 2, pp. 118-130.

Fu X., Zhu Q., Sarkis J., Evaluating green supplier development programs at a telecommunications systems provider, "International Journal of Production Economics" 2012, no. 140, pp. 357-367.

Ghijsen P.W.T., Semeijn J., Ernstson S., Supplier satisfaction and commitment: The role of influence strategies and supplier development, "Journal of Purchasing and Supply Management" 2010, vol. 16, no. 1, pp. 17-26.

Giménez C., Tachizawa E.M., Extending sustainability to suppliers: A systematic literature review, "Supply Chain Management" 2012, vol. 17, no. 5, pp. 531-543.

Goebel P., Reuter C., Pibernik R., Sichtmann C., The influence of ethical culture on supplier selection in the context of sustainable sourcing, "International Journal of Production Economics" 2012, no. 140, pp. 7-17.

Hafezalkotob A., Competition of domestic manufacturer and foreign supplier under sustainable development objectives of government, "Applied Mathematics and Computation" 2017, no. 292, pp. 294-308.

Hahn C.K., Watts C.A., Kim K.Y., The Supplier Development Program: A Conceptual Model, "Journal of Purchasing and Materials Management" 1990, vol. 26, no. 2, pp. 2-7. 
Humphreys P.K., Li W.L., Chan L.Y., The impact of supplier development on buyer-supplier performance, "Omega" 2004, vol. 32, no. 2, pp. 131-143.

Jia F., Zuluaga L., Bailey A., Rueda X., Sustainable supply chain management in developing countries: An analysis of the literature, "Journal of Cleaner Production" 2018, no. 189, pp. 1-14.

Jiang P., Hu Y.Ch., Yen G.F., Tsao S.J., Green supplier selection for sustainable development of the automotive industry using grey decision-making, "Sustainable Development" 2018, no. 26, pp. 890-903.

Krause D.R., Ellram L.M., Critical elements of supplier development: The buying-firm perspective, "European Journal of Purchasing and Supply Management" 1997, vol. 3, no. 1, pp. 21-31.

Krause D.R., Handfield R.B., Tyler B.B., The relationships between supplier development, commitment, social capital accumulation and performance improvement, "Journal of Operations Management" 2007, vol. 25, no. 2, pp. 528-545.

Krause D.R., Scannell T.V., Calantone R.J., A Structural Analysis of the Effectiveness of Buying Firms' Strategies to Improve Supplier Performance, "Decision Sciences" 2000, vol. 31, no. 1, pp. 33-55.

Leenders M.R., Suppliers development, "Journal of Purchasing” 1966, vol. 24, pp. 47-62.

Li S., Kang M., Haney M.H., The effect of supplier development on outsourcing performance: the mediating roles of opportunism and flexibility, "Production Planning and Control" 2017, vol. 28, no. 6-8, pp. 599-609.

Lin C.T., Hung K.P., Hu S.H., A Decision-Making Model for Evaluating and Selecting Suppliers for the Sustainable Operation and Development of Enterprises in the Aerospace Industry, "Sustainability" 2018, no. 10, pp. 1-21.

Lu R.X.A., Lee P.K.C., Cheng T.C.E., Socially responsible supplier development: Construct development and measurement validation, "International Journal of Production Economics" 2012, no. 140 , pp. 160-167.

Luzzini D., Amann M., Caniato F., Essig M., Ronchi S., The path of innovation: Purchasing and supplier involvement into new product development, "Industrial Marketing Management" 2015, vol. 47, pp. 109-120.

McAuley L., Pham B., Tugwell P., Moher D., Does the inclusion of grey literature influence estimates of intervention effectiveness reported in meta-analyses?, "The Lancet" 2000, vol. 356, no. 9237 , pp. $1228-1231$.

Modi S.B., Mabert V.A., Supplier development: Improving supplier performance through knowledge transfer, "Journal of Operations Management" 2007, vol. 25, no. 1, pp. 42-64.

Nagati H., Rebolledo C., Supplier development efforts: The suppliers' point of view, "Industrial Marketing Management" 2013, vol. 42, no. 2, pp. 180-188.

Orłowska A., Mazur Z., Łaguna M., Systematyczny przegląd literatury: Na czym polega i czym różni się od innych przeglądów, "Ogrody Nauk i Sztuk” 2017, no. 7, pp. 350-363.

Porter M.E., Competitive Advantage: Creating and Sustaining Superior Performance, The Free Press, New York 1985.

Rogers Z.S., Carter C.R., Kwan V., Making tough choices: A policy capturing approach to evaluating the tradeoffs in sustainable supplier development initiatives, "Journal of Purchasing and Supply Management" 2019, no. 25, pp. 1-12.

Sancha C., Longoni A., Giménez C., Sustainable supplier development practices: Drivers and enablers in a global context, "Journal of Purchasing and Supply Management" 2015, vol. 21, no. 2, pp. 95-102.

Sancha C., Giménez C., Sierra V., Kazeminia A., Does implementing social supplier development practices pay off?, "Supply Chain Management" 2015, vol. 20, no. 4, pp. 389-403.

Seuring S., Müller M., From a literature review to a conceptual framework for sustainable supply chain management, "Journal of Cleaner Production" 2008, no. 16, pp. 1699-1710. 
Shabanpour H., Yousefi S., Saen R.F., Forecasting efficiency of green suppliers by dynamic data envelopment analysis and artificial neural networks, "Journal of Cleaner Production" 2017, no. 142, pp. 1098-1107.

Slavin R.E., Best evidence synthesis: an intelligent alternative to meta-analysis, "Journal of Clinical Epidemiology" 1995, vol. 48(1), pp. 9-18.

Su H.N., Lee P.C., Mapping knowledge structure by keyword co-occurrence: A first look at journal papers in technology foresight, "Scientometrics" 2010, no. 85(1), pp. 65-79.

Sundin E., Ohrwall Ronnback A., Sakao T., From component to system solution supplier: Strategic warranty management as a key to efficient integrated product/service engineering, "CIRP Journal of Manufacturing Science and Technology" 2010, no. 2, pp. 183-191.

Talluri S., Narasimhan R., A methodology for strategic sourcing, "European Journal of Operational Research" 2004, vol. 154, no. 1, pp. 236-250.

Talluri S., Narasimhan R., Chung W., Manufacturer cooperation in supplier development under risk, "European Journal of Operational Research" 2010, vol. 207, no. 1, pp. 165-173.

Tan J., Zailani S., Green Value Chain in the Context of Sustainability Development and Sustainable Competitive Advantage, "Global Journal of Environmental Research" 2009, vol. 3(3), pp. 234-245.

United Nations Conference on Environment \& Development Rio de Janerio, Brazil, 3 to 14 June 1992 AGENDA 21, https://sustainabledevelopment.un.org/content/documents /Agenda21.pdf (accessed: 21.10.2019).

Vermeulen M., Oosthuizen G.A., Strategic Local Manufacturing Supplier Development Roadmap as a Decision Support Tool, "Procedia Manufacturing" 2019, no. 33, pp. 594-601.

Waas T., Verbruggen A., Wright T., University research for sustainable development: definition and characteristics explored, "Journal of Cleaner Production", May 2010, vol. 18, issue 7, pp. 629-636.

Wang C.N., Huang Y.F., Le T.N., Ta T.T., An Innovative Approach to Enhancing the Sustainable Development of Japanese Automobile Suppliers, "Sustainability" 2016, no. 8, pp. 1-19.

Webster J., Watson R.T., Analyzing the past to prepare for the future: Writing a literature review, "MIS Quarterly" 2002, vol. 26, no. 2, pp. 13-23.

Wong C.W.Y., Lai K., Shang K.C., Lu C.S., Leung T.K.P., Green operations and the moderating role of environmental management capability of suppliers on manufacturing firm performance, “International Journal of Production Economics" 2012, no. 140, pp. 283-294.

Wu G.C., Effects of Socially Responsible Supplier Development and Sustainability-Oriented Innovation on Sustainable Development: Empirical Evidence from SMEs, "Corporate Social Responsibility and Environmental Management" 2017, no. 24, pp. 661-675.

Zhang M., Pawar K.S., Bhardwaj S., Improving supply chain social responsibility through supplier development, "Production Planning and Control" 2017, vol. 28, no. 6-8, pp. 500-511.

Zimmer K., Frohling M., Schultmann F., Sustainable supplier management - a review of models supporting sustainable supplier selection, monitoring and development, "International Journal of Production Research" 2016, vol. 54, no. 5, pp. 1412-1442. 


\section{Abstract}

The purpose of the article was to conduct a systematic analysis of reviewed scientific publications covering the subject of sustainable development of suppliers.

Bibliometric and contextual analysis allowed the formulation of the following conclusions: 1) the issue of sustainable development of suppliers is present in peer-reviewed scientific publications to a very moderate level, 2) the small number of publications does not make it possible to determine whether there is a trend in terms of publication time, 3) scientific journals in which articles on sustainable development of suppliers were published have a different profile, 4) authors who undertake the issues analyzed come from different countries, 5) sustainable development of suppliers is the subject of research in a range of research areas. Following a systematic review of the literature, proposals for future research directions were also formulated.

Keywords: suppliers, sustainable development, systematic literature review 